\title{
Carbonates and associated sedimentary rocks of the Upper Viséan to Namurian Mabou Group, Cape Breton Island, Nova Scotia: evidence for lacustrine deposition*
}

\author{
T.L. Crawford \\ Department of Earth Sciences, Dalhousie University, Halifax, Nova Scotia B3H 3J5, Canada
}

Date Received September 11, 1995

Date Accepted December 14, 1995

\begin{abstract}
The Upper Viséan to Namurian Mabou Group of Cape Breton Island conformably overlies highest marine carbonate strata of the Windsor Group and unconformably (? also conformably) underlies the mainly fluviatile Cumberland Group. Regionally, the Mabou Group, dominated by fine grained clastic rocks, comprises a lower grey facies assemblage of proposed lacustrine origin, and an upper red facies of fluviatile origin. The grey facies is represented by the Hastings Formation in western Cape Breton Island, by the Cape Dauphin Formation in the Sydney Basin, and by the lower parts of the MacKeigan Lake Formation in the Loch Lomond Basin of southeastern Cape Breton Island. The red facies comprises the Pomquet Formation in western Cape Breton Island, the Point Edward formation in the Sydney Basin, and the upper part of the MacKeigan Lake Formation. The ubiquitous presence of thin, laterally discontinuous limestone beds in the lower grey facies of the Mabou Group is a useful guide to stratigraphic position. These carbonate beds include wackestones and grainstones containing intraclasts and ooids as well as ostracods and serpulids. Stromatolites are the most common carbonate rock type within the grey facies of the Mabou Group. Faunal elements characteristic of normal marine environments are conspicuously absent. The carbonate rocks and associated siliciclastic sediments indicate that deposition of the Mabou Group grey facies occurred within a shallow subaqueous environment undergoing intermittent periods of sub-aerial exposure, a setting consistent with lacustrine conditions, traditionally postulated for lower Mabou Group sedimentation. Initially elevated salinities reflecting the last stages of marine evaporite sedimentation gave way progressively to brackish and then fresh-water conditions as the Late Viséan arid climate moderated during earliest Namurian time.
\end{abstract}

Le Groupe du Viséen supérieur au Namurien de Mabou, sur l'île du Cap-Breton, recouvre de façon concordante les strates marines de carbonates les plus élevées du Groupe de Windsor et il est sous-jacent de façon discordante (également concordante ?) au Groupe essentiellement fluviatile de Cumberland. Régionalement, le Groupe de Mabou, dominé par des roches clastiques à grain fin, englobe un assemblage inférieur de faciès gris qu'on propose être d'origine lacustre ainsi qu'un faciès supérieur rouge d'origine fluviatile. Le faciès gris est représenté par la Formation Hastings dans l'ouest de l'île du Cap-Breton, par la Formation Cape Dauphin dans le bassin de Sydney et par les parties inférieures de la Formation MacKeigan Lake dans le bassin de Loch Lomond, dans le sud-est de l'île du Cap-Breton. Le faciès rouge comprend la Formation Pomquet dans l'ouest de l'île du Cap-Breton, la formation Point Edward dans le bassin de Sydney et la partie supérieure de la Formation MacKeigan Lake. La présence omniprésente de couches discontinues de calcaire dans le faciès inférieur gris du Groupe de Mabou constitue un guide utile sur sa position stratigraphique. Ces strates de carbonates comprennent des wackestones et des grainstones qui renferment des intraclastes et des oolithes de même que des Ostracodes et des serpules. Les stromatolithes constituent le type de roches carbonatées les plus répandues à l'intérieur du faciès gris du Groupe de Mabou. Les éléments fauniques caractéristiques des milieux marins normaux sont manifestement absents. Les roches carbonatées et les sédiments silicoclastiques révèlent que la sédimentation du faciès gris du Groupe de Mabou est survenue à l'intérieur d'un milieu subaquatique peu profond soumis à des périodes intermittentes d'exposition subaérienne, c.-à-d. un cadre compatible avec les conditions lacustres, postulé par le passé en ce qui touche la sédimentation de la partie inférieure du Groupe de Mabou. Les salinités initialement élevées correspondant aux derniers stades de la sédimentation marine d'évaporite ont progressivement été remplacées par des eaux saumâtres puis de l'eau douce au fur et à mesure que le climat aride du Viséen supérieur s'est adouci au tout début du Namurien.

[Traduit par la rédaction]

\section{INTRODUCTION}

Carboniferous rocks in eastern Canada, with the notable exception of the Middle to Upper Viséan Windsor Group of marine origin, have traditionally been assigned to a broad range of non-marine environments (see, for example, Bell, 1944, 1958; Belt, 1965, 1968). Recent work by Wightman et al. (1993), Thibaudeau (1993), and Gibling and Bird (1994)

* Geological Survey of Canada Contribution No. 322295.

Atlantic Geology

31, 167-182 (1995) 
has alluded to intermittent marine deposition, particularly for Late Carboniferous time. Gibling and Bird (1994) have, for example, suggested parallels with classical Pennsylvanian cyclothemic sedimentation for the Late Carboniferous (Westphalian) depositional regime in the Maritimes Basin.

The Upper Viséan to Namurian (Neves and Belt, 1970; Utting, 1987) Mabou Group, defined by Belt (1968), conformably overlies the highest marine strata of the Windsor Group in Nova Scotia. In this stratigraphic position, it is the most likely of all post-Windsor Group successions within the Maritimes Basin to show marine influence. Detailed mapping of the Carboniferous succession of western Cape Breton Island (Giles et al., in press (a), (b)) has revealed that intercalated carbonate rocks are ubiquitous and characteristic of the lower part of the Mabou Group in that area. Detailed examination of these carbonates was undertaken to more fully document their character and their stratigraphic utility, and to test the proposed lacustrine model by determining any indications for marine versus non-marine origin.

Data for this study originate from five well-exposed sections in western Cape Breton Island (Fig. 1), including parts of Belt's Mabou Group type section. On the northwestern flanks of the Sydney Basin, the type section of the correlative Cape Dauphin Formation was selected for detailed examination to provide more regional appraisal of carbonate facies variation. Two additional sections provided by continuously cored drill holes were selected for comparative study in southeastern Cape Breton Island (Fig. 1). In all these sections, the carbonate rocks were studied using slabbed hand-specimens and standard petrographic thin sections. The work was undertaken as part of a B.Sc. (Honours) thesis completed in 1995 at Dalhousie University.

\section{Previous work}

Rostoker (1960) informally divided the grey and red, fine grained sedimentary rocks of the Canso Group within the Antigonish Basin and western Cape Breton Island into a lower grey unit, termed the Hastings Formation, and an upper red unit, termed the Pomquet Formation.

Belt (1964) established the name Mabou for the Canso Group, raising the Mabou Formation of Norman (1935) to group status while recommending abandonment of Canso as a formal group name. Belt (1964) interpreted the lower Mabou Group to be of lacustrine origin. In 1965, Belt undertook a comprehensive analysis of regional stratigraphy and sedimentology of uppermost Viséan to lower Namurian strata in Atlantic Canada. In this study Belt formalized the Hastings and Pomquet formations. These lithostratigraphic units, the definition of which has been modified slightly by Giles et al. (in press (a), (b)), comprise the entire Mabou Group in western Cape Breton Island. In 1968, Belt published his interpretation of regional Carboniferous depositional environments. This study includes descriptions of the rock units of the Mabou Group and the carbonate rocks that are intercalated in the lower Mabou Group. Belt (1968) identified laterally linked stromatolites, oolitic calcarenites, intraclast calcarenites, and laminated calcilutites, and reiterated his interpretation of a lacustrine setting for the lower Mabou Group. Additional evidence provided by Belt (1968), suggesting a lacustrine environment of deposition, includes the presence of pelecypods and arthropods (Ostracoda and Conchostraca).

Within the grey facies of the Mabou Group, Copeland (1957) identified non-marine arthropod species of Tealliocaris, Lynceites and Dithyrocaris. Intercalated with these non-marine species, were the brackish-water ostracod genera Paraparchites and Beyrichiopsis, that Copeland suggested may indicate the highest occurrence of Carboniferous brackish-water deposition. Copeland (1957) also noted Carbonita fabulina, a freshwater ostracod, associated with the brackish-water ostracod species.

Neves and Belt (1970) identified microfloral assemblages of Vallatisporites ciliaris, Schulzospora elongata, Grandispora spinosa, and Potoniesporties elegans. Through comparisons of these assemblages with those of Britain and Northern Spain, Neves and Belt (1970) concluded that the Mabou Group is of Late Viséan to Early Namurian age. Utting (1987) assigned the lower part of the Mabou Group, near the Windsor Group contact, to a Late Viséan age based on the dominance of Crassispora trychera within the succession.

\section{Geological setting AND REGIONAL STRATIGRAPHY}

Carboniferous rocks in western Cape Breton Island flank the Cape Breton Highlands. They also underlie large areas in the Sydney Basin and in central parts of the island. These strata range in age from latest Devonian to latest Carboniferous (Bell and Howie, 1990) and provide the local record of sedimentation in this portion of the Maritimes Basin as defined by those authors. The present configuration of Carboniferous outcrop areas is that of variably sized basins, largely structural in definition but possibly reflecting Carboniferous depositional sub-basins as well (Bell, 1944, 1958).

In its type area in western Cape Breton Island, the Mabou Group comprises the lower, Hastings Formation and the overlying Pomquet Formation (Fig. 2). The group is conformable on strata of the uppermost Windsor Group where normal stratigraphic relationships are preserved. The WindsorMabou contact is placed at the top of the El limestone member (Stacey, 1953) of the Hood Island Formation (uppermost Windsor Group), as recommended by Boehner and Giles (1993). In many parts of western Cape Breton Island, lower Mabou Group strata are in faulted contact with older Windsor Group rocks where juxtaposed by movement on the Ainslie Detachment (Lynch and Giles, in press). This relationship is postulated at Ainslie Point (Fig. 1) on the basis of map patterns and proximity of lowermost Mabou Group strata to the basal Windsor, Macumber Formation.

Because the upper part of the Windsor Group is conformable with the Mabou Group, the character of the Windsor Group is important to the understanding of the depositional setting for the Mabou. The Hood Island Formation (uppermost Windsor Group) comprises a series of carbonate members, variably fossiliferous and clearly of marine origin, overlain 


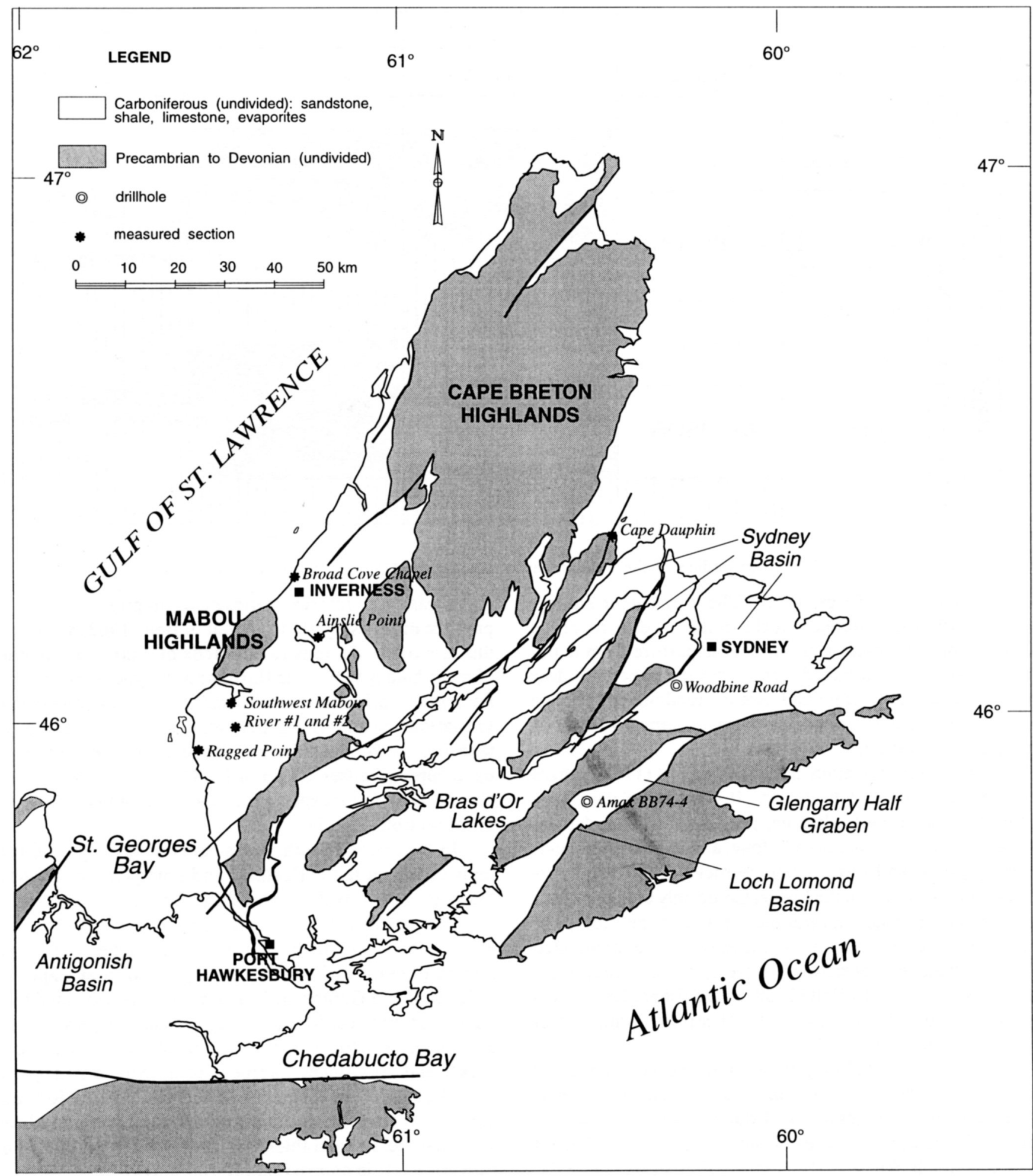

Fig. 1. Location map of Cape Breton Island, Nova Scotia showing the positions of measured sections and drillholes.

in cyclically repeated patterns by sulphate evaporites capped by relatively thick red siltstones. The latter, interpreted by virtue of facies relationships in the carbonate rocks, represent non-marine sedimentation during periods of marine withdrawal from the basin. Evaporites in the upper part of the Windsor Group represent the most marginal marine facies, extending in part into the sabkha environment (Schenk,
1969). In surface exposures, the highest marine carbonate within the Hood Island Formation is typically overlain by gypsum up to $20 \mathrm{~m}$ thick, and then siltstones of the lowermost Mabou Group. Intercalated anhydrite and salt also occur within the lower Mabou Group in the subsurface, preserved in drill core from the Shubenacadie Basin in southcentral Nova Scotia (Boehner, 1980) and the Antigonish 


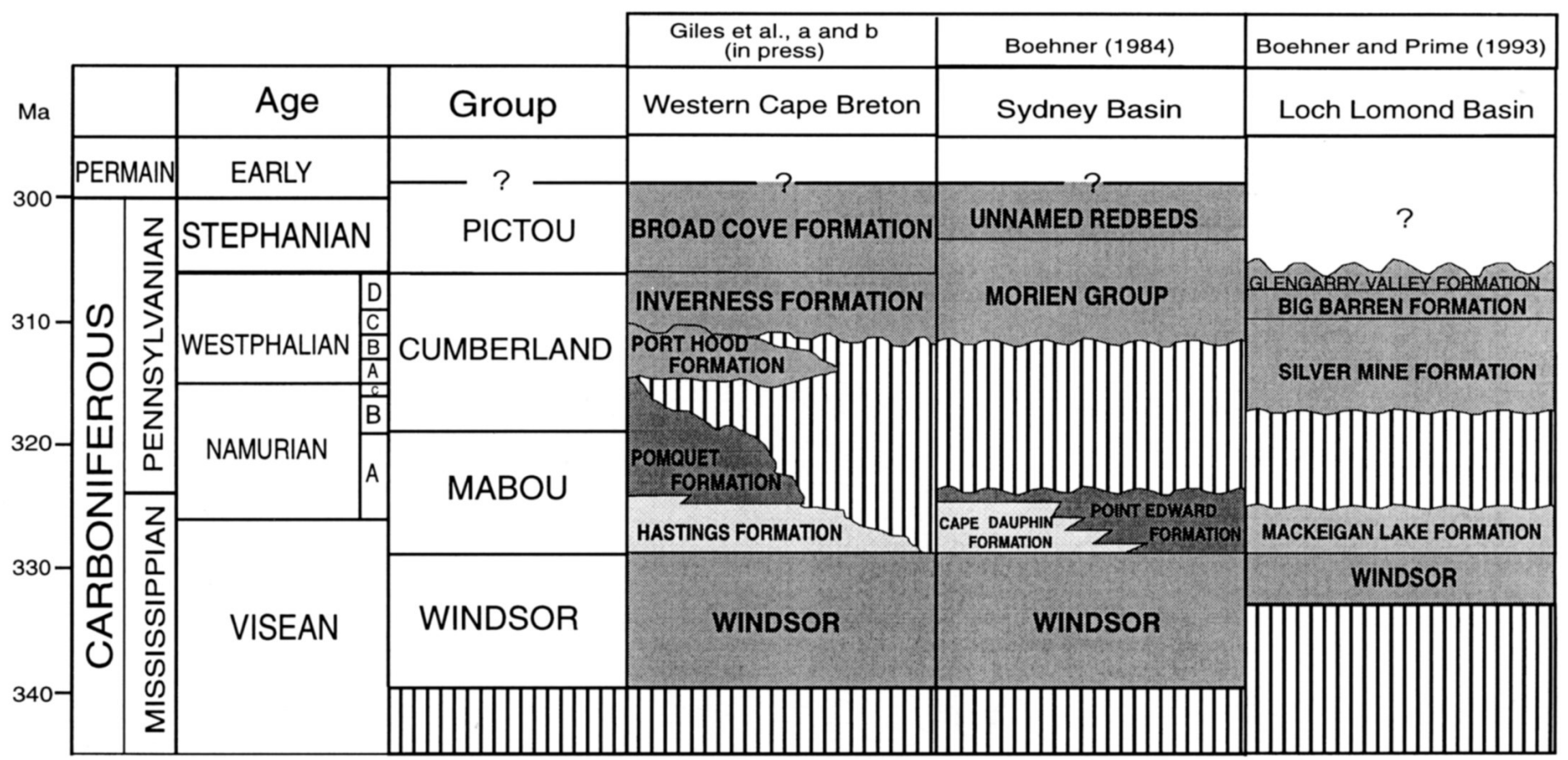

Fig. 2. An outline of the stratigraphy of the Mabou Group in the study area.

Basin (Boehner and Giles, 1993). The grey colour and association with thin carbonate rocks in the lower parts of the Mabou Group represent a significant departure from depositional patterns established throughout the upper Windsor Group. The basin therefore underwent a fundamental change in the latest Viséan, coincident with the onset of Mabou Group sedimentation.

The Hastings Formation, as defined by Belt (1965), ranges in thickness from 425 to $765 \mathrm{~m}$. It consists of dark grey shale, grey calcareous siltstone, grey dolomitic mudstone, grey and red non-calcareous siltstone, and interbedded sandstone, gypsum, and thin carbonate rocks. Significant carbonate rocks are found in the Mabou Group only in the Hastings Formation or its lithostratigraphic equivalents and comprise $5 \%$ of the section, with minor carbonate rocks associated with the Pomquet Formation. In western Cape Breton Island, rocks assigned by Belt (1968) to the Emery Brook Formation are considered part of the Hastings Formation of Giles et al. (in press (a), (b)).

According to Belt (1965), the Pomquet Formation reaches a maximum thickness of $5490 \mathrm{~m}$. Boehner and Giles (1993) considered this is excessive and due to extrapolation in a structurally complicated area of the section; they estimated the maximum thickness of the Pomquet Formation to be 3900 m. As mapped by Giles et al. (in press (a), (b)), the Pomquet Formation is composed totally of red-brown siltstone with relatively minor, interstratified fine grained sandstone, also typically red-brown. Thin, discontinuous nodular calcretes are found within the Pomquet Formation but carbonate rocks comparable to those seen in the underlying Hastings Formation have not been documented.

In western Cape Breton Island, the contact between the Hastings and Pomquet formations is transitional through intertonguing of red and grey facies assemblages. The top of the Hastings Formation is placed at the top of the highest significant grey interval (Giles et al., in press (a), (b)). This practice differs slightly from that of Belt (1968) who named discrete intervals, tens to hundreds of metres in thickness, of red lithology within the Hastings as tongues of the Pomquet Formation. Facies transition between the Hastings and Pomquet formations on a more regional scale results in the local juxtaposition of Pomquet Formation facies assemblages directly upon upper Windsor Group rocks. This relationship has been observed in coastal exposures about $1 \mathrm{~km}$ south of the Ragged Point section (Fig. 1).

In the Sydney Basin, rocks equivalent in age and lithologic character to the Hastings and Pomquet formations are assigned respectively to the Cape Dauphin and Point Edward formations (Fig. 2; Bell and Goranson, 1938; Giles, 1983). The Cape Dauphin Formation reaches a maximum known thickness of $90 \mathrm{~m}$ at its type section at Cape Dauphin (Bell and Goranson, 1938) where it is truncated by the Upper Carboniferous Morien Group. It comprises grey laminated and blocky siltstones, carbonaceous shales, thin carbonate rocks, and significant interbeds of anhydrite and gypsum near the base of the formation. The Point Edward formation consists of fine- to medium-grained sandstone, red-brown and siltstone. Its total thickness, measured in drill hole Point Edward 84-1, is approximately $106 \mathrm{~m}$ (Boehner, 1985).

Giles (1983) showed that red facies typical of the Point Edward formation may locally overlie the uppermost Windsor Group beds without the intervening grey facies of the Cape Dauphin Formation. He also documented facies transition between the Point Edward and Cape Dauphin formations, both laterally and in vertical succession. In the Sydney Basin, the Cape Dauphin Formation in its type section is overlain with angular unconformity by lowermost conglomerates and sandstones of the Westphalian C-D Morien Group. This same unconformity separates the Point Edward formation from the Morien Group (Giles, 1983). 
In the Loch Lomond area of southeastern Cape Breton, Boehner and Prime (1993) assigned rocks similar to both the Hastings and Pomquet formations of the type Mabou Group to a single lithostratigraphic unit termed the MacKeigan Lake Formation (Fig. 2). The lower MacKeigan Lake Formation, about $80 \mathrm{~m}$ in thickness, is predominantly grey and contains laminated siltstones, dolomitic mudstones, gypsum, and carbonaceous shales, with minor red siltstones, and red and grey, interbedded fine- to medium-grained sandstones. Carbonate rocks similar to those at the type section of the Hastings Formation are intercalated. The upper MacKeigan Lake contains predominantly red, fine- to medium-grained sandstones, with carbonate rocks lacking. In the Glengarry Half Graben, the Mabou Group is disconformably overlain by Upper Namurian to Lower Westphalian deposits (Boehner and Prime, 1993). In this study, I have equated the lower part of the MacKeigan Lake Formation with the Hastings Formation on the basis of lithology and comparable age (Late Viséan - Namurian; Boehner and Prime, 1993).

The Mabou Group is overlain by sandstone-dominated successions of the coal-bearing Cumberland Group in western Cape Breton Island, and by the equivalent Morien Group in the Sydney Basin. The contact relationship is typically unconformable, and significant portions of the upper Mabou Group may be locally absent, as at Cape Dauphin where strata of middle Namurian to Westphalian B are not represented (Boehner, 1984). In the Loch Lomond Basin the Silver Mine Formation of the Cumberland Group disconformably overlies the MacKeigan Lake Formation (Boehner and Prime, 1993).

For ease of reference, rocks of the Hastings and Cape Dauphin formations, and the lower portion of the MacKeigan Lake Formation can be collectively assigned to a lower grey facies of the Mabou Group. The Pomquet Formation and Point Edward formation comprise an upper red facies of the Mabou Group.

\section{Carbonate rocks}

\section{Stromatolites}

Stromatolites, the most common and obvious form of carbonate rock of the Mabou Group, comprise up to $60 \%$ of all the carbonate strata. Stromatolites were noted in all sections measured and range in thickness from 4 to $60 \mathrm{~cm}$. Stromatolite colonies vary in their lateral continuity, occurring as single isolated colonies, discontinuous colonies within discrete layers at a particular stratigraphic level, and laterally continuous forms that can be traced for tens of metres in gently dipping exposures. Common forms of stromatolites within the Mabou Group include laterally-linked hemispheroids (Logan et al., 1964) (Fig. 3), horizontally laminated types, oversteepened forms (Fig. 4), and more complex stromatolites combining these types (Fig. 5).

Stromatolites of the Mabou Group grey facies contain well-developed laminae that occur as multiple couplets. The laminae consist of alternating dark grey and buff layers that range from 0.2 to $3 \mathrm{~mm}$ thick. The buff coloured laminae are sediment-rich consisting predominantly of carbonate grains,

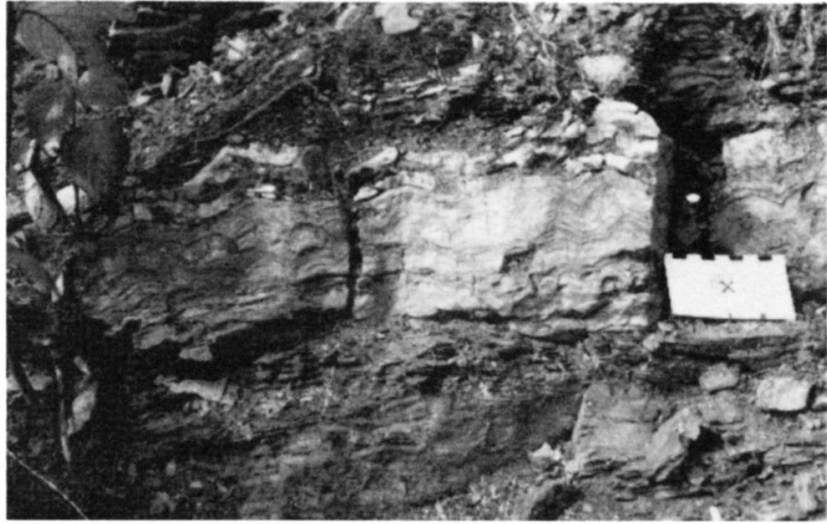

Fig. 3. Laterally-linked hemispheroidal stromatolite, overlying dark grey shale of the Hastings Formation, Ainslie Point. The stromatolite is laterally discontinuous in outcrop.

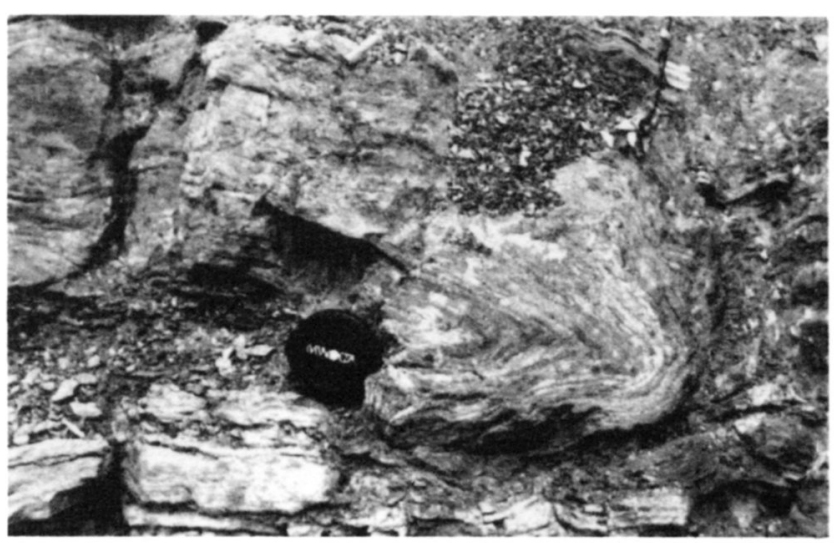

Fig. 4. Oversteepened stromatolite from the Hastings Formation, Southwest Mabou River \#1. (Lens cap $=5.5 \mathrm{~cm}$ diameter)

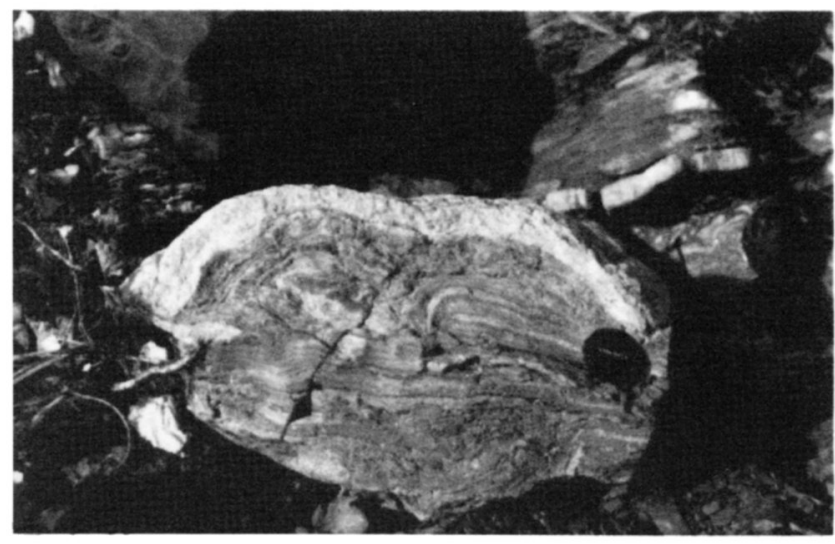

Fig. 5. Compound stromatolite from the Hastings Formation, Ainslie Point. The basal portion is comprised of a flat-pebble conglomerate. Laminae, in the middle portion of the stromatolite, overlying the conglomerate are discontinuous and overturned. The upper surface consists of continuous wavy laminations, in turn topped by a corrugated surface. (Lens cap $=5.5 \mathrm{~cm}$ diameter)

whereas the dark grey laminae are organic-rich. Ooids and fine grained quartz and feldspar are scattered within the laminae of some stromatolites (Fig. 7). These grains com- 


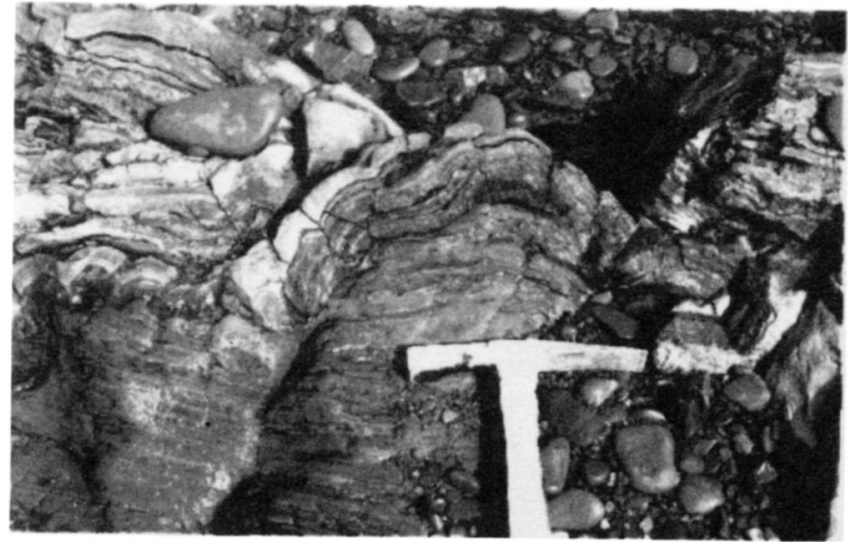

Fig. 6. Stromatolite developed on top of previously eroded laminated grey siltstones from the Hastings Formation, Broad Cove Chapel. Note the two orders of curvature. (Hammer head $=21$ cm long)

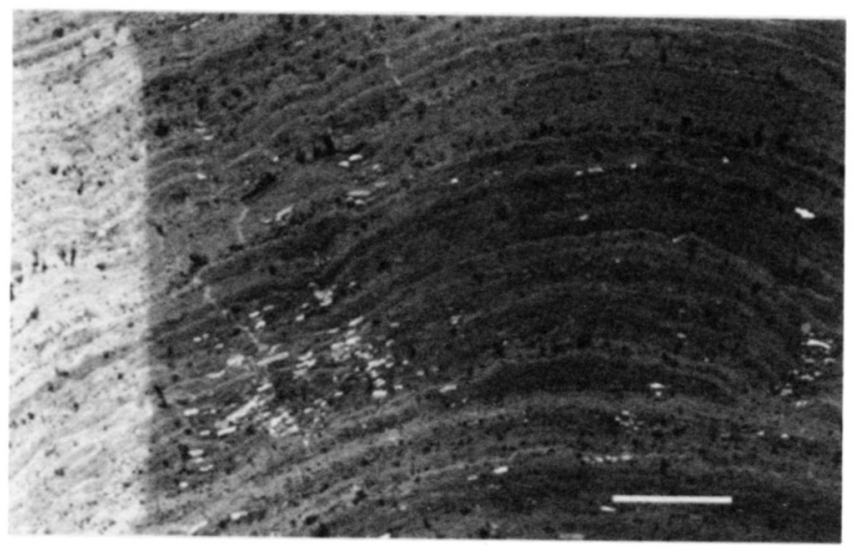

Fig. 7. Thin section negative print of laminae within a stromatolite from the Hastings Formation, Southwest Mabou River \#1. Note the alternating light and dark laminae containing elongate grains oriented with their long axis parallel to the growth surface of the stromatolite. (Scale bar $=5 \mathrm{~mm}$ )

monly orient themselves with their long axis parallel to the growth surface of the stromatolite. The laminae may be planar, domal, corrugate, or a combination of these with first and second orders of curvature (Fig. 6).

Internal texture of the Mabou Group stromatolites generally consists of patchy micrite, ranging from brown to green under plane-polarized light. Some samples exhibit well-developed, radially fibrous calcite cement layers $(<0.5 \mathrm{~mm})$ separated by thin micrite bands. Others possess a fenestral texture with pore spaces infilled with spar calcite.

In laterally-linked hemispheroids, such as those at Southwest Mabou River \#1 and Broad Cove Chapel sections, individual hemispheroids range in diameter from 7 to $17 \mathrm{~cm}$. The oversteepened forms exist as asymmetrical domes in which the laminae are oriented roughly parallel to bedding. Other oversteepened laminae are symmetrical domes that have been folded over to lie on their side, as seen in a compound stromatolite at Ainslie Point (Fig. 5).

Stromatolites of the Mabou Group may drape irregularly over previously eroded beds (Fig. 6), or may have sharp planar contacts with underlying sediments. Stromatolites commonly overlie grey laminated siltstones that sometimes contain low amplitude ripple marks, desiccation cracks, or flat-pebble conglomerates. The stromatolites generally are overlain by grey laminated siltstones.

\section{Interpretation}

The sharp contact between the base of stromatolites and underlying sediments suggests an abrupt change in depositional conditions. These changes may have resulted from periods of erosion associated with decreases in water level or changes in the chemistry of the lake, thereby allowing calcium carbonate to precipitate. Growth of microorganisms that contribute to stromatolite development may be inhibited by increased water turbidity. Stromatolites that have developed on top of flat-pebble conglomerates probably established themselves on mudflats shortly after flooding (Eugster and Hardie, 1975).

The discontinuous stromatolites that appear as discrete domal colonies may represent small algal reefs, irregularly distributed along a shoreline, perhaps all forming at roughly the same time. These stromatolites developed on siltstones showing ripple marks and desiccation cracks, suggesting that they formed in relatively shallow waters, where subaerial exposure is common.

The presence of multiple couplets of laminae in the stromatolites suggests an alternating series of processes, namely mechanical trapping of detrital carbonate and cyanobacterial growth. The buff-coloured laminae are carbonate rich, whereas the dark grey laminae may represent organic-rich layers. In recent stromatolites from the Trucial Coast, Park (1976) identified dark grey laminae as being organic-rich and consisting of cyanobacteria.

Laminae on top of oversteepened stromatolites that are roughly equal to those on the underside of symmetrical domes suggest that the stromatolites grew upward before they were overturned. Some of the oversteepened stromatolites (Southwest Mabou River \#1) are asymmetrical suggesting that their overall growth morphology may have been influenced by current action.

\section{Grainstones}

Grainstones of the Mabou Group grey facies range in thickness from 5 to $25 \mathrm{~cm}$, and occur in all sections measured. The grainstones generally are laterally continuous, although some are lensoidal, and contain finely laminated elongate grains, or intraclasts, and structureless carbonate grains. Grains range from 0.1 to $50 \mathrm{~mm}$ in the longest dimension and have well-rounded to irregular edges: they may be well-sorted with their long axis parallel to bedding or poorly sorted with no preferred orientation. Under this heading, I have included packstones and wackestones (Dunham's Classification, Dunham, 1962) as they have the same types of clasts and comprise a small percentage of the carbonate rocks.

The laminated grains, or intraclasts, noted in the Mabou Group grey facies contain alternating buff and grey, millimetrescale laminae that are generally planar and parallel or wavy. 
A number of these laminated grains consist of layers of fine grained spar calcite alternating with micritic laminae, which are similar to the laminae noted in the lower Mabou Group stromatolites. At Broad Cove Chapel and Southwest Mabou River \#1, intraclastic grainstones are generally noted directly underlying, and in some cases overlying stromatolites.

The non-laminated grains are micritic and structureless. Within a grainstone immediately overlying a stromatolite, stratigraphically high in the Broad Cove Chapel section, the grains possess a thin $(0.02 \mathrm{~mm})$, radially fibrous calcite rim (Fig. 8). Some of these rims are buckled and indent the edges of neighbouring grains, with spar calcite cement existing in spaces between the grains and the rims. These particular grains are rod-shaped, well-rounded, wellsorted, and range from 0.5 to $2 \mathrm{~mm}$ long. The grains have a strong preferred orientation parallel to lamination in the underlying stromatolite.

Structureless grains in a sample from the Southwest Mabou River \#1 section are well-rounded, spherical to elliptical, and appear to have undergone compaction, evident by a spastolithic texture (Fig. 9), suggesting that they were soft for some time after deposition. These grains vary from black in the centre to light brown towards the exterior. Sparry calcite cement fills the intergranular spaces in most of the rock, although micritic matrix occurs in some parts. The matrix of Mabou Group grainstones consists of predominantly pore-filling, spar calcite cement (Fig. 10), whereas wackestones in the section contain silt-size quartz and feldspar enclosed within calcareous micrite (Fig. 11). The porefilling cement within the grainstones shows a general increase in crystal size toward the centre of the pore space, resulting in an interlocking mosaic. Ooids contribute less than $5 \%$ of all grains present within these grainstones.

At Ragged Point, questionable serpulids (Fig. 12) occur within two separate wackestones stratigraphically high in the Mabou Group grey facies. These grainstones reach a maximum thickness of $10 \mathrm{~cm}$ and are lensoidal. Serpulids are sessile organisms that excrete planispirally coiled calcareous tubes. The wall structure of the questionable serpulids within the Hastings Formation consists of tiny parallel wavy laminae. The exterior of these fossilized tubes bears concentric ridges, giving them a ribbed appearance, with a thin coating of micrite along the inner and outer edges. Porefilling, sparry calcite cement, feldspar, or calcareous micrite rich in silt- and sand-size quartz grains, may fill the innermost part of the serpulid chambers. The matrix around the tubes ranges from a calcareous micrite with abundant quartz grains to a spar calcite.

Serpulids have a close affinity to certain classes of gastropods, sometimes causing considerable uncertainty in their identification (Burchette and Riding, 1977; Weedon, 1990). Although the identification of Mabou Group serpulids is admittedly tentative, both comparable gastropods and serpulids inhabit a primarily marine environment (Burchette and Riding, 1977; Weedon, 1990), so that the significance of these fossil coiled tubes to environmental synthesis is not negated by this uncertainty.

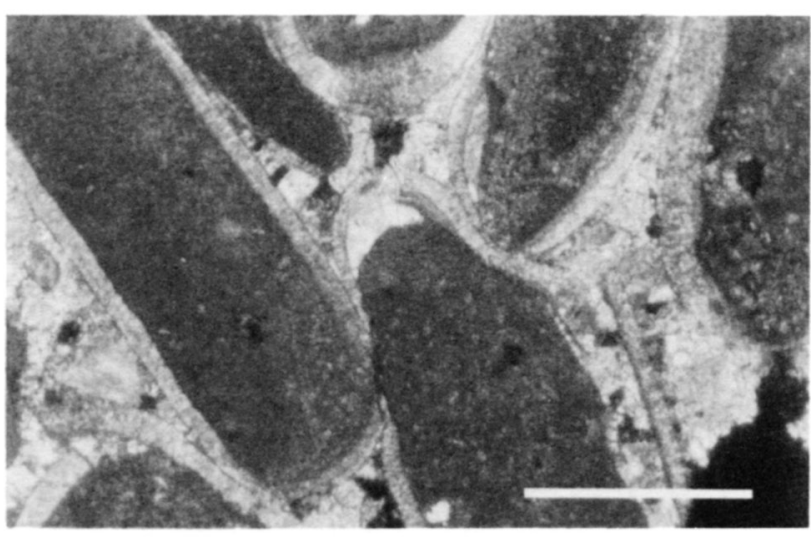

Fig. 8. Grainstone from the Hastings Formation, Broad Cove Chapel. Well-rounded flat-pebbles, which have a radially fibrous calcite rim, from 0.5 to $2 \mathrm{~mm}$ long. They are well sorted and imbricated within a spar to micrite cement. The presence of buckled rims suggests compaction of the grains. (Scale bar $=0.25 \mathrm{~mm}$; cross polarized)

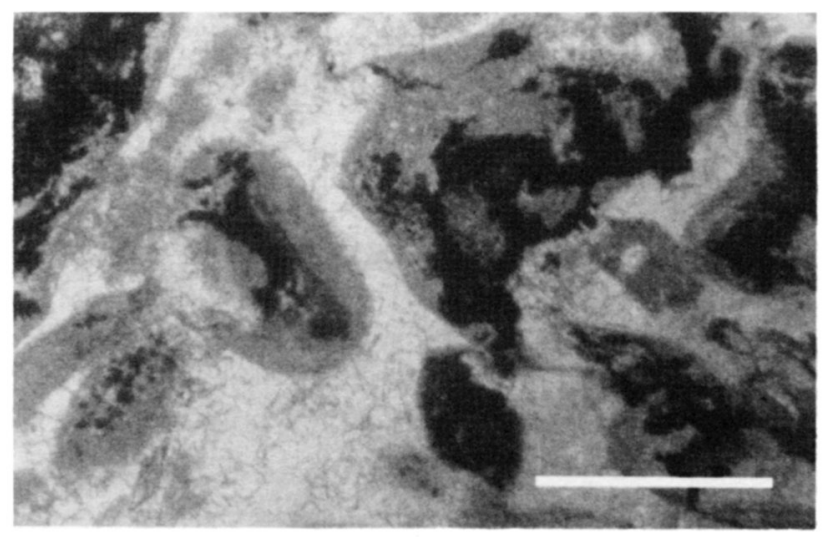

Fig. 9. Grainstone from the Hastings Formation, Southwest Mabou River \#1. Micritic grains of variable colour within a spar cement. Note compaction of the grains as indicated by the presence of a spastolithic texture. (Scale bar $=0.25 \mathrm{~mm}$; plane polarized)

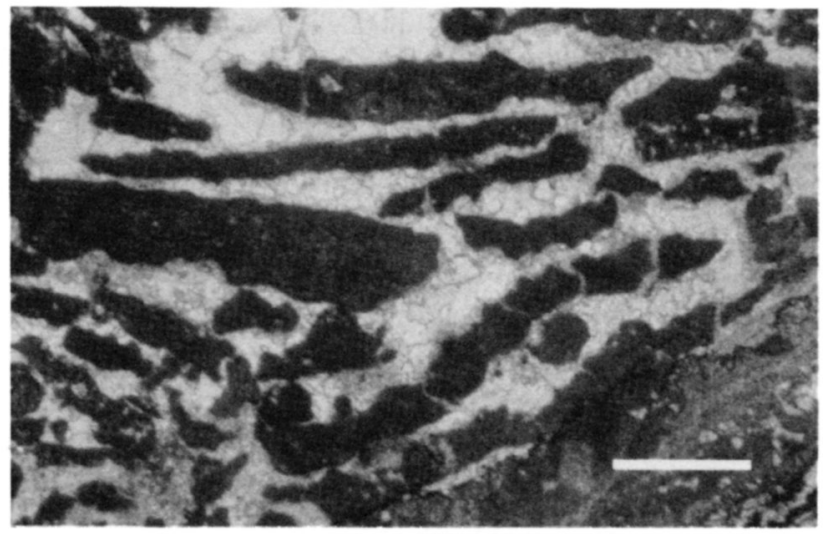

Fig. 10. Intraclastic grainstone. The intraclasts appear to be fragments derived from the algal mat in the upper left-hand corner. This sample comes from the Hastings Formation, Ainslie Point. (Scale bar $=0.5 \mathrm{~mm}$; plane polarized) 


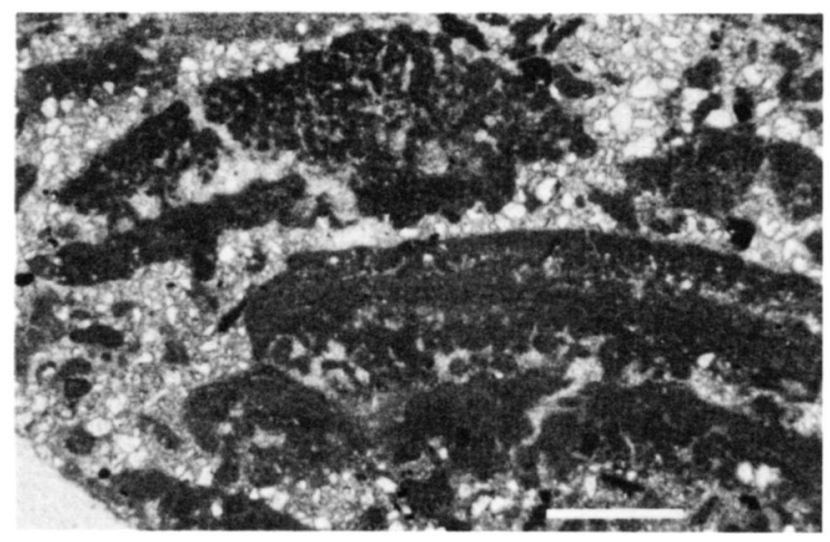

Fig. 11. Intraclastic packstone. Intraclasts are porous fragments derived from algal mats or stromatolites. The sediment between the intraclasts is muddy with abundant silt-size quartz-grains. This sample comes from the Hastings Formation, South west Mabou River \#1. (Scale bar $=0.5 \mathrm{~mm}$; plane polarized)

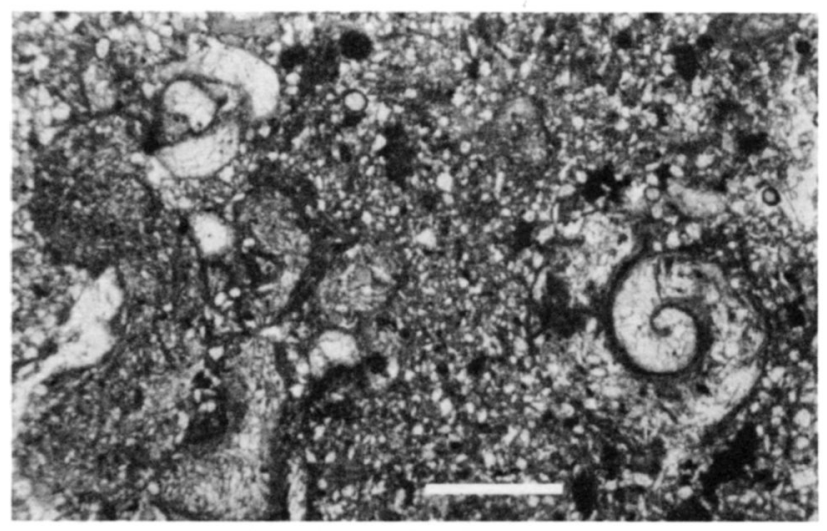

Fig. 12. Serpulid wackestone from the Hastings Formation, Ragged Point. Well-preserved coiled serpulid tubes enclosed in a siliciclastic matrix with abundant silt-size quartz grains. (Scale bar $=0.5$ $\mathrm{mm}$; plane polarized)

\section{Interpretation}

Intraclasts within grainstones from the Mabou Group grey facies include those derived from fine grained carbonate sediments and those of stromatolite, or algal mat, origin (Fig. 10). Non-stromatolitic intraclasts noted in the Mabou Group may be fragments of reworked muds. The algal fragments probably originated from nearby stromatolites. Flatpebble conglomerates, or intraclastic grainstones, represent a transgressive lag deposit formed when a shallow lake expanded over an exposed mud flat. During periods of regression, muds and stromatolites were exposed and subjected to desiccation cracking. Processes of drying and algal mat binding made these clasts coherent enough for high-energy wave transport (Eugster and Hardie, 1975).

Pore-filling spar calcite cement generally develops in environments where water occupies all the pore spaces, allowing precipitation of calcite crystals without obstacles (Longman, 1980). Intraclasts enclosed in a sparry cement (Fig. 10) suggest that mud did not occupy the pore spaces around the intraclasts during cementation. Thus, the intraclasts were either deposited by currents that winnowed muds out of the pore spaces, or the intraclasts accumulated too rapidly for the mud to contaminate them (Dunham, 1962). A muddy or micritic matrix between intraclasts (Fig. 11) indicates relatively quiet waters in which active currents did not wash fine grained muddy sediment out of the pore spaces. Minor amounts of micrite may alternatively have infiltrated the pore-spaces of the sediments following deposition.

In the grains from the Southwest Mabou River \#1 section (Fig. 9) that display colour variations, the black may be of organic origin whereas the brown may reflect leaching of the organic matter. These grains consist of dense micrite, making their origin difficult to determine.

Buckled rims and indented edges of grains (Fig. 8), noted in samples from the Broad Cove Chapel section, suggest that tight packing and compaction occurred after the development of the calcitic coat. Calcite cement subsequently filled spaces produced when rims buckled and peeled away from the peloid (or the growth of calcite caused the rims to buckle).

Serpulid are not common in the lower Mabou Group and do not indicate any specific environment, although they are subaqueous organisms that tolerate a broad range of salinity including brackish to marine waters (Burchette and Riding, 1977; Tasch, 1980; Weedon, 1990). Serpulids commonly occur with algal laminates and stromatolites (Burchette and Riding, 1977).

\section{Ooids}

Oolitic grainstones occur as several thin beds within the grey facies of the Mabou Group at Ainslie Point, Broad Cove Chapel, and Southwest Mabou River \#1. These grainstones are laterally continuous and range in thickness from $15 \mathrm{~cm}$ at Southwest Mabou River \#1 to $1 \mathrm{~m}$ at Ainslie Point.

A massive, parallel laminated, oolitic grainstone reaching a maximum thickness of $1 \mathrm{~m}$ occurs at Ainslie Point, North Lake Ainslie. Abundant algal fragments occur within the lowermost $17 \mathrm{~cm}$ of this oolite. The middle part of the 00lite consists mainly of ooids, 0.25 to $1 \mathrm{~mm}$ in diameter, and closely packed within a micritic cement containing scattered silt- and sand-size quartz grains. In parts of the rock, a porefilling sparry calcite occurs between the ooids. Individual ooids possess well-developed concentric and radially fibrous structures. In about $30 \%$ of the ooids, sparry calcite cement replaces the inner cortex (Fig. 13). Some ooids possess a nucleus of either micrite or quartz grains, whereas in others the original nucleus is not evident. Thin sections from the middle part of the Ainslie Point oolite contain ooids that are closely packed asymmetric forms and show pressuresolution at the contacts of some ooids (Fig. 7). Stylolites that cut across the ooids and cement are also noted in this oolite.

Within the uppermost $24 \mathrm{~cm}$ of this oolite, ostracod fragments act as nuclei for ooid formation (Fig. 14). In this part of the rock, the ooids are larger, ranging in size from 0.2 to $3.5 \mathrm{~mm}$ in diameter. Generally one thick radial coat develops around individual or clusters of ostracod fragments (Fig. 14). The inner parts of the ostracod chambers contain a thin 


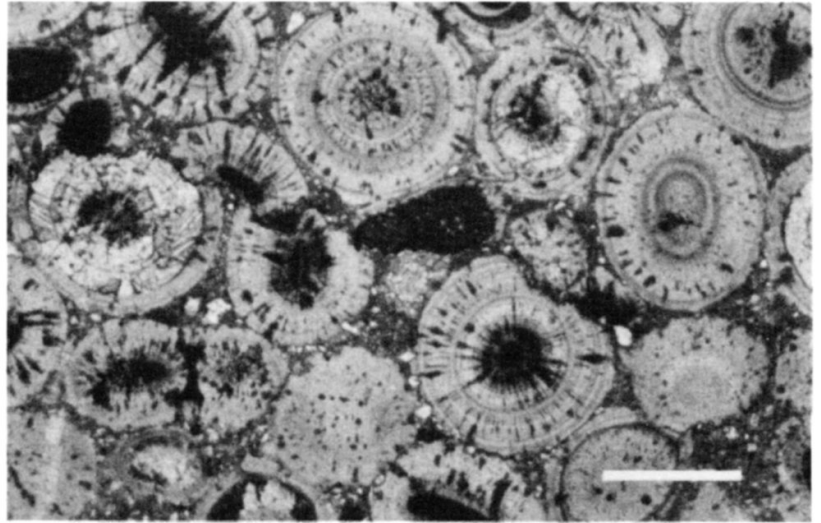

Fig. 13. Oolitic packstone from the Hastings Formation, Ainslie Point. Ooids show well-developed radial and concentric structures and nuclei consisting of micritic grains. The ooids are well sorted within a siliciclastic matrix. Note stylolite through the centre of the photo and replacement of the cortexes of some of the ooids by spar calcite. (Scale bar $=0.5 \mathrm{~mm}$; plane polarized)

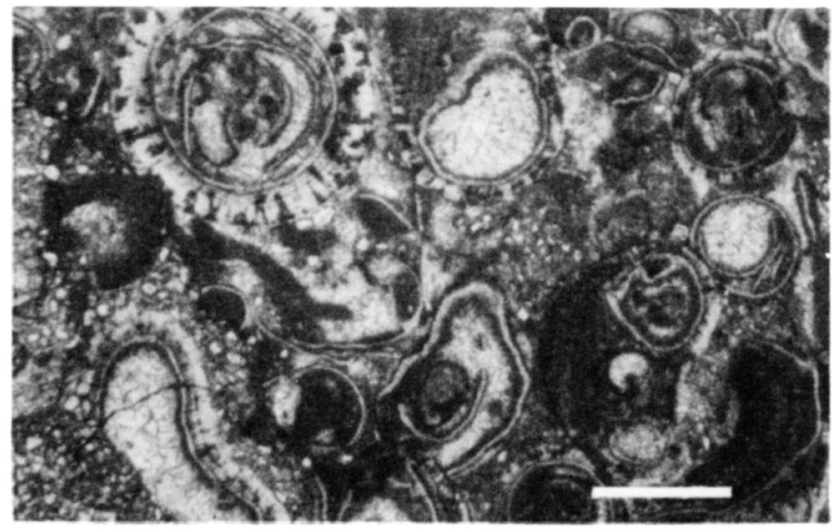

Fig. 14. Oolitic packstone from the Hastings Formation, Ainslie Point. The ooid nuclei consist of fragments of ostracods infilled with spar cement, but not all the ostracods have an oolitic coating. Ooids occur within a poorly sorted muddy matrix containing quartz grains. (Scale bar $=0.5 \mathrm{~mm}$; plane polarized)

coat of micrite and are subsequently infilled by patches of pore-filling sparry calcite. The part of the rock consisting predominantly of these ooids is poorly sorted with scattered siliciclastic material in the matrix.

A cross-bedded, $24 \mathrm{~cm}$ thick, oolitic grainstone from the Southwest Mabou River \#1, contains well-rounded, spherical to elliptical ooids. The ooids have well-developed radial and concentric structure and contain cores of quartz and/or micrite. They range in diameter from 0.25 to $1 \mathrm{~mm}$. Void-filling spar calcite envelops loosely packed and well-sorted ooids. Calcite crystals decrease in number and increase in size toward the pore space. In another part of the same rock, the ooids are less abundant and are enclosed in a micritic cement containing serpulid fragments. A remnant meniscus micritic film coats some ooids in this sample (Fig. 15).

Ooids from Broad Cove Chapel have radial to concentric structure around a nucleus of micrite and/or quartz grains. Figure 16 shows the loosely packed, well-rounded, spheri-

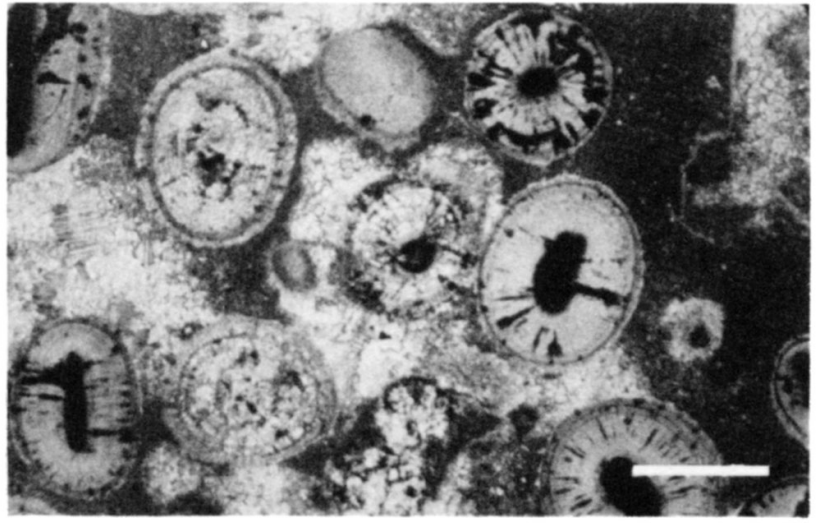

Fig. 15. Oolitic grainstone from the Hastings Formation, Southwest Mabou River \#1. Note the micritic meniscus cement formed around the ooids. Spar calcite fills the rest of the pore space. (Scale bar $=0.5 \mathrm{~mm}$; plane polarized)

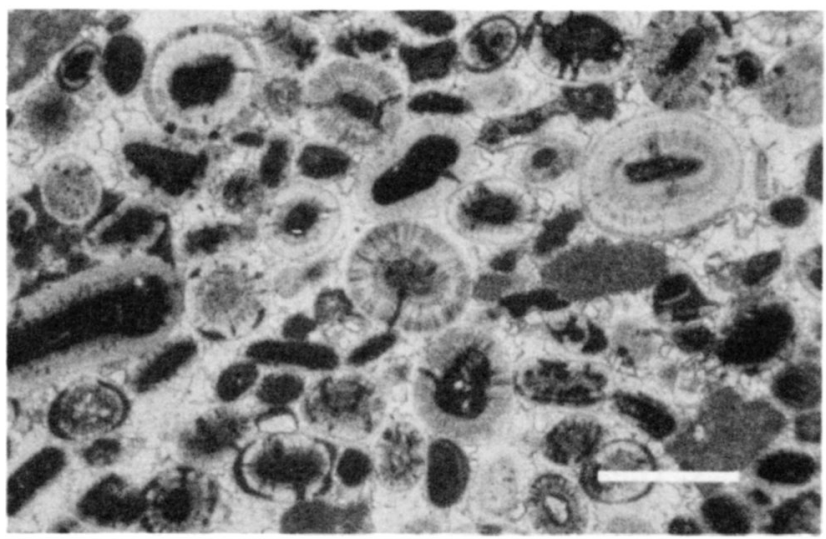

Fig. 16. Oolitic grainstone from the Hastings Formation, Broad Cove Chapel. The ooids are spherical to elliptical exhibiting well-developed radial and concentric structures with nuclei ranging from micritic carbonate to quartz grains. Ooids and a small number of intraclasts are poorly sorted within pore-filling spar cement. (Scale bar $=0.5 \mathrm{~mm}$; plane polarized)

cal to elliptical ooids. A spar calcite cement infills the pore spaces existing between the loosely packed ooids and occasional intraclasts. One oolitic grainstone stratigraphically high in the Broad Cove Chapel section contains sparse serpulids.

\section{Interpretation}

The presence of ooids in the Mabou Group suggests a shallow subaqueous environment, with a low rate of sediment influx. Characteristically, ooids form in warm, clear, shallow, wave-agitated marine and hypersaline waters saturated with respect to calcium carbonate (Swirydczuk et al., 1979; Reijers and ten Have, 1983). In modern environments, ooids form where calcium carbonate precipitates because of a rapid loss of carbon dioxide and an increase in salinity in warm shallow waters generally less than 2 to $5 \mathrm{~m}$ in depth (Simone, 1981).

The arrangement of ooid fibres provides information about energy level of the waters in which the ooids formed. 
Turbulence and periodic abrasion may modify radial fibres to tangential fabrics in a higher energy environment by mechanically flattening the ooid surfaces (Davies et al., 1978). Radial textures form in slightly deeper waters that are weakly agitated and calcium carbonate supersaturated (Reijers and ten Have, 1983). Variations in ooid structure in samples studied suggest that energy levels of the waters in which they formed were changing, or that the ooids were transported to environments with different energy levels. In samples, such as the Ainslie Point oolite, ooids have a radial structure in the centre and a concentric structure in the cortex.

Meniscus cements form in vadose environments related to a loss of carbon dioxide, as in ooid production (Sellwood, 1986). Generally, a meniscus cement forms when capillary forces hold water between grains in zones where the pores periodically contain water, characteristic of a vadose zone (Longman, 1980). Vadose zones generally undergo frequent wetting and drying.

Samples that have stylolites cross-cutting the ooids and sutured contacts between the ooids, imply that these oolites were subjected to compaction soon after formation because of overburden stress. Localized strain at grain to grain boundaries in saturated solutions and pressure-dissolution along the contacts, resulted in the formation of sutures (Bathurst, 1975).

\section{ASSOCIATED SEDIMENTARY ROCKS}

\section{Siltstone}

Siltstones are the dominant lithology of the Mabou Group grey facies. They range from grey to green to red, with grey being prevalent. The siltstones are either laminated and wellbedded, or non-stratified and exhibit blocky weathering.

The most distinctive rock type within the grey facies is a dark grey, finely laminated siltstone. Millimetre-scale laminae occur as couplets of dark grey, organic-rich shale alternating with light grey, calcareous siltstone. The light grey laminae weather buff to yellow have a calcareous cement, and are parallel or wavy to lenticular. This siltstone displays a fissile to platy weathering, is well stratified, and thinly bedded. Desiccation cracks, thin pyrite laminations $(<1-2 \mathrm{~mm})$, and occasional low-amplitude ripple marks also characterize these siltstones.

Interbeds of grey dolomitic mudstone, associated with the laminated siltstones, range from 2 to $20 \mathrm{~cm}$ in thickness. They weather to a buff colour and occur as resistant ledges within more easily eroded siltstones. The mudstones are continuous to laterally discontinuous lenses in outcrop, possess a conchoidal fracture, are commonly finely banded and well indurated. Belt (1968) considered these beds to be a diagnostic characteristic of his Hastings Formation.

Another siltstone present in the lower Mabou Group exhibits blocky and swaley fractures. This siltstone ranges from grey to red to purplish-red, often exhibits small-scale slickensides on fracture surfaces, and possess millimetresize rooted horizons.

\section{Interpretation}

Laminated grey siltstones such as those of the Hastings Formation are characteristic lake-basin deposits, representing seasonal variations in sediment supply and organic productivity (Tucker, 1978). Their grey colouring and well-preserved laminae suggest that reducing conditions existed where few grazers lived. Horizontal pyrite laminae in the siltstones also provide evidence for a reducing environment. Minor, small-scale, straight-crested ripples suggest that water depths were relatively shallow and imply periodic water flow and, almost certainly, oxygenation. The presence of desiccation cracks and halite pseudomorphs (salt casts) suggests that this relatively shallow water environment was periodically exposed. Laminated dolomitic mudstones that occur as resistant beds within the laminated siltstones record quiet water sedimentation of carbonate material out of suspension.

Not all the siltstones are grey, or laminated. They may occur as grey, green, or red massive, blocky siltstones with conchoidal fracture and root traces. Some of these may be interpreted as vertisols, resulting from alternating periods of swelling and shrinking (Retallack, 1988). Other fine grained clastic rocks within the lower Mabou Group consist of dark grey to black bituminous shales that may result from the accumulation of organic material under anaerobic conditions.

\section{Sandstone}

Sandstones in the grey facies consist predominantly of red and green, fine- to medium-grained quartz-rich sands. They may exhibit climbing ripples, cross-stratification, and a calcareous matrix. The sandstones consist of well-sorted, quartz-rich sands generally interstratified with siltstones, with beds ranging from 2 to $135 \mathrm{~cm}$ in thickness, and averaging 30 to $70 \mathrm{~cm}$. Shaly partings commonly separate individual sandstone beds. Fining-upward sequences in the sandstones consist of a massive medium- to coarse-grained sand at the base containing red intraclastic mud chips, fining-up to fine grained sandstone characterized by climbing ripples, and overlain by red and grey siltstone. Characteristic features of the sandstones are calcareous cements, minor plant debris, cross laminae, and low-amplitude wave ripples. Less common features of the Mabou Group sandstones include halite pseudomorphs and pelecypods.

\section{Interpretation}

Belt (1968) defined similar fining-upward sequences within the Mabou Group red facies as fluvial channel sandstones, suggesting that rivers occasionally flowed into the lake or over periodically exposed parts of the lake bottom or mudflat environment. Exposure of the sediments would result in oxidation with lowering of watertable and, if exposed for long enough periods, the establishment of plants and pedogenic carbonates. Some sandstones exhibit a mottled or 
variegated nature, possibly due to the presence of plant roots that formed reduction spots in the red sediments.

\section{Gypsum}

Gypsum, interbedded with red and grey siltstone, occurs in the lower $40 \mathrm{~m}$ of the grey facies at Ragged Point, Broad Cove Chapel, Woodbine Road, and MacKeigan Lake. The gypsum, better preserved in drill core than in surface exposures, ranges from white satin spar veins to dark grey and brown parallel-bedded gypsum, with bladed selenite crystals and rosettes. Minor anhydrite occurs at the base of the drill core from Woodbine Road, immediately overlying the highest limestone of the upper Windsor Group. Satin spar veins crosscut and lie parallel to bedding surfaces, most commonly cutting siltstone and shale interbedded with more massive gypsum beds.

In a single bed of fine grained red sandstone at Broad Cove Chapel are relict diagenetic sulphate nodules, preserved as hollow, lobate calcite-lined spheroids up to $6 \mathrm{~cm}$ in longest dimension.

\section{Interpretation}

The presence of thick anhydrite/gypsum (western Cape Breton Island) and salt (Shubenacadie Basin, Boehner, 1980) deposits within the lower $80 \mathrm{~m}$ of the grey facies suggests that high salinity waters, coupled with high evaporation rates, still existed following deposition of the Windsor Group. Evaporite deposits in the Mabou Group occur intercalated with grey mudstones and siltstones, in contrast to the underlying Windsor Group in which evaporites occur in association with red siliciclastic rocks. This change from red to grey, fine grained clastic rocks associated with evaporite deposits may be indicative of a transition from an inland sea to a lake.

The occurrence of relict sulphate nodules at Broad Cove Chapel attests to conditions of high evaporitic drawdown in the diagenetic environment. Their presence suggests that the host sandstone was subjected to periods of subaerial exposure, if not deposited in a subaerial environment.

\section{ENVIRONMENTAL SYNTHESIS}

The depositional setting of the lower Mabou Group was, in large part, established by the environment and processes which governed sedimentation of the cyclic marine and nonmarine upper Windsor Group. Schenk et al. (1994) illustrated how the interaction of evaporite precipitation and subsidence, during the first cycle of marine sedimentation in the Windsor Group in Middle Viséan time, would have readily filled much of the initial relief in the basin. The regional distribution of the lower Windsor evaporites of Cycle 1 (Giles, 1981) suggests that this process of early basin filling operated over an area at least as large as the present Gulf of St. Lawrence. Similar patterns of sedimentation throughout the middle portions of the Windsor Group would have contributed to a progressive removal of any remaining sea floor relief, resulting in an essentially flat-floored basin. Areas peripheral to the basin, and rare high-standing areas within, provided local sediment sources. Moore and Austin (1979) showed that the Herbert River Limestone (basal upper Windsor) was deposited on a sea floor dipping at less than 1 degree. This flat-floored basin, ultimately exposed as an immense plain following each cyclic marine regression, was the setting for deposition of the Mabou Group.

The gypsum beds overlying the highest Windsor carbonate for up to 80 to $100 \mathrm{~m}$, although assigned to the lowermost Mabou Group by mapping practice, are clearly the culmination of the last Windsor carbonate-evaporite cycle. The preservation of lamination in the gypsum immediately above the El limestone at the Broad Cove Chapel section (Fig. 17) indicate deposition of the sulphate from standing water. Salt units $10 \mathrm{~m}$ thick occur in the lower Mabou Group equivalents of the Shundenacadie Basin (Boehner, 1980). Boehner (personal communication, 1995) believes that these salts, because of their thickness and relatively high purity, are of subaqueous deposition. The initial environment of deposition for the lowermost Mabou Group can therefore be reasonably postulated as hypersaline marine.

The grey, fine grained siliciclastic rocks with associated carbonates of the Mabou grey facies provide ample evidence for sedimentation in a shallow subaqueous environment. Planar lamination in siltstones, the preservation of pyrite laminae and carbonaceous material, and the intercalation of thin dolomitic mudstones collectively suggest deposition in a subaqueous environment. Oolitic carbonates are shallow water deposits, as are most stromatolites in the geological record. Common, low-amplitude ripple marks in grey Mabou siliciclastics attest to shallow water conditions.

Stromatolites such as those seen in the grey facies of the Mabou Group are not diagnostic of specific environments. They are, however, quite different from stromatolites in the underlying Windsor Group. The latter, particularly where associated with marine evaporites, are commonly thrombolitic in internal structure, lacking the fine lamination so prevalent in Mabou Group stromatolites (P.S. Giles, personal communication, 1995). Some Windsor stromatolites are also laminated like Mabou forms, thus rendering this distinction of uncertain importance to environmental interpretation.

Stromatolite growth requires photic conditions and a supply of small carbonate grains to generate successive laminae due to organic binding. The nature of the trapped grains cannot be determined due to their fine grain size, although they occur with larger identifiable grains. The fine grained accreted material might represent detrital material or inorganically precipitated calcium carbonate. Modern stromatolites occur in aquatic environments ranging from freshwater to hypersaline (Hofmann, 1973). Their morphology is controlled by biologic and sedimentologic factors which are not environmentally specific. Only the associated sedimentary rocks and sedimentary structures can provide clues to the depositional setting.

Evidence for subaerial exposure includes desiccation cracks, rooted horizons indicated by rhizomal concretions (rare) and 


$\begin{array}{ccc}\begin{array}{c}\text { Cape Dauphin } \\ \text { (Sydney Basin) }\end{array} & \begin{array}{c}\text { Woodbine Road } \\ \text { (Sydney Basin) }\end{array} & \begin{array}{c}\text { Amax BB74-4 } \\ \text { (Loch Lomond Basin) }\end{array}\end{array}$

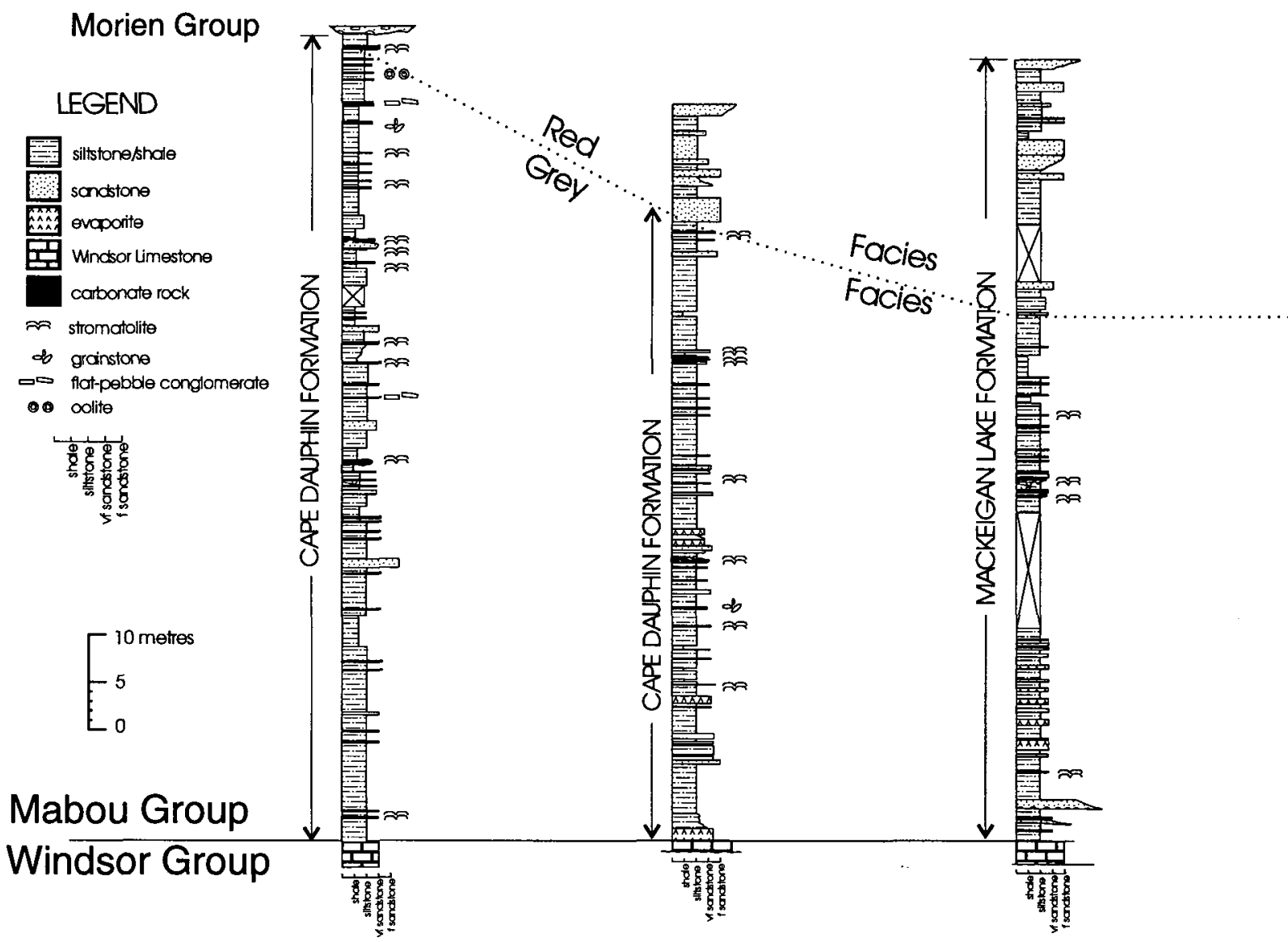

Fig. 17. Stratigraphic sections measured and drill core logged of the lower Mabou Group, Cape Breton Island. For locations refer to Figure 1.

vertisol horizons, and intraclastic carbonate beds, closely associated with stromatolites in the lower Mabou Group. The flat-pebble beds, where composed of laminated carbonate intraclasts, are indicative of short-lived episodes of exposure, desiccation, and flaking or spalling of stromatolitic fragments. Inundation of these surfaces resulted in incorporation of the flaky debris into the overlying bed. The presence of thin intervals showing evidence for subaerial exposure, interbedded with planar-laminated subaqueous grey shales and siltstones, argues for periodic changes in water depth.

Evidence for elevated salinities in the depositional environment includes the presence of thin intercalated gypsum beds, several tens of metres above the basal gypsum (Ragged Point and Woodbine Road sections, Fig. 17). Casts of halite in hopper-shaped crystals, noted at Broad Cove Chapel and Southwest Mabou \#1 sections in grey, fine grained sandstone and grey siltstone respectively, indicate high evaporation rates and elevated salinities. Copeland (1957) noted brackish-water ostracods in the lower part of the Mabou Group, including the species Paraparchites and Beyrichiopsis. Copeland also reported the non-marine arthropods Tealliocaris, Lynceites and Dithyrocaris in the lower Mabou Group. These fossils, in beds with intercalated evaporites, show that fluctuations from hypersaline to brackish-marine to non-marine condi- tions were a feature of the lower Mabou depositional regime. Serpulids reported here for the first time in the lower Mabou Group grey facies are salinity tolerant, ranging from marine to brackish-water environments (Tasch, 1980; Weedon, 1990). They occur well above the base of the Mabou Group, near the top of the grey facies at the Ragged Point section (Fig. 1; Fig. 17) and very near the transition to Mabou red facies at the Broad Cove section (Fig. 1; Fig. 17). These problematic organisms attest to at least short-lived, nearmarine conditions high in the grey facies.

The general paucity of body and a scarcity of trace fossils indicates that the depositional environment was generally hostile to all but the most tolerant organisms. This may be attributed to euxinic conditions for much of the grey facies, or to salinity stress. The latter might be caused by elevated or depressed salinities, or by relatively rapid fluctuations in salinity. No marine fossils comparable to those found in the immediately underlying Windsor Group have been reported from the Mabou Group, in spite of a long history of study. This suggests that truly marine conditions were never achieved during Mabou sedimentation.

Thin intercalations of fine grained red beds within the Mabou grey facies are attributed to intermittent migration of the shoreline, permitting incursion of continental red sedi- 


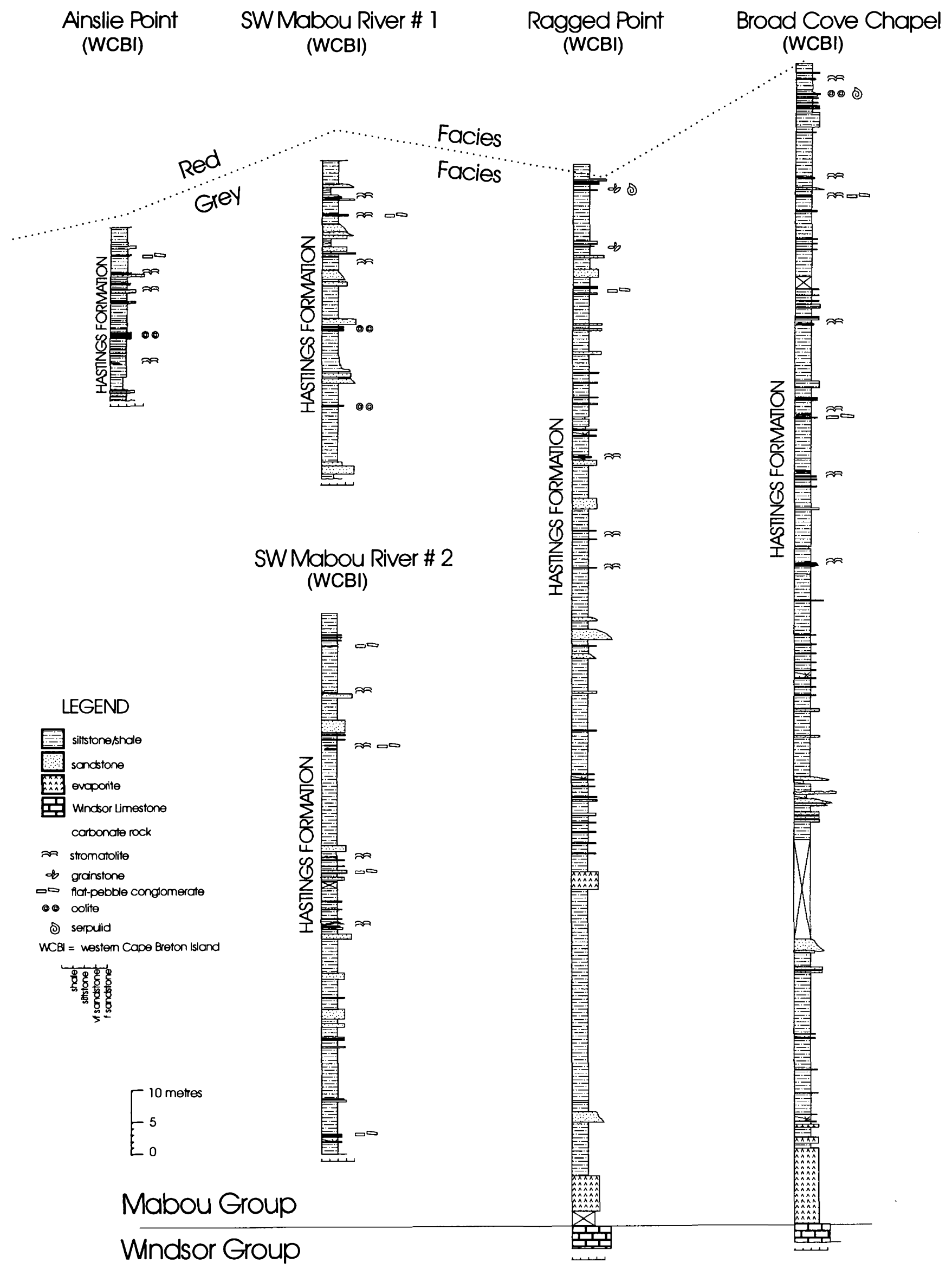

Fig. 17 Continued. 
ments over the adjacent, formerly subaqueous environment. The occasional occurrence of small bivalves in these red sediments suggests that they were deposited in a setting subjected to at least periodic wetting. Thicker intercalations of red material are similar to beds seen in the overlying red facies of the Mabou Group and are interpreted as fine grained fluviatile deposits. Copeland (1957) reported the conchostracan fauna of Leaia baentschiana and Leaia acutilirata of freshwater origin from rocks of the upper Mabou Group (red facies). Their presence supports an interpreted non-marine depositional setting.

In summary, the depositional history of the lower Mabou Group reflects a period of transition from the marine Windsor Group to the continental beds of the upper red facies of the Mabou Group. Most rocks of the grey facies were deposited in a shallow body of standing water subject to large fluctuations in salinity.

It seems evident that the grey facies of the Mabou Group was not deposited under conditions of normal marine salinity, or one might reasonably expect to find carbonates with facies and faunas comparable to those in the Windsor Group. Nor was it deposited under persistent hypersaline conditions such as one might postulate for a marine evaporite basin, for such conditions yielded thick and regionally extensive evaporite deposits in the preceding Windsor Group in the same regional depocentres. The basin in which the Mabou Group was initially deposited was marine and hypersaline, as indicated by an abundance of evaporites at the base of the succession. A gradual decrease in the abundance of evaporites up-section documents a significant decrease in overall salinity as the basin evolved to a lacustrine setting.

A lacustrine environment best accommodates the variability in salinity observed in the lower Mabou Group, while allowing for rapid and variable concentrations of salts in solution. Short-lived re-establishment of marine connections could explain the brackish faunas and the occasional return to hypersaline conditions due to replenishment of ions depleted through precipitation. The success of marine organisms even with wide salinity tolerance in colonizing this environment during marine incursions of short duration would be limited. In the evolution of the marine-evaporite basin to a continental basin, some evaporitic components of the water could be derived from redissolved Windsor Group sediments in marginal areas of an internally drained basin.

Climate, initially arid, began to ameliorate to one of seasonal aridity with episodes of more moderate conditions, as indicated by the appearance of vertisols in the lower Mabou Group. Vertisols are unknown in the Windsor Group. The appearance of calcretes in the red facies of the Mabou Group is also indicative of a wet-dry seasonal climate. In this climatic regime, any body of water lacking persistent marine connections would be subject to fluctuations in water level and salinity depending on the season and on the chemistry of terrestrial waters entering the basin.

The high degree of similarity of Mabou Group facies assemblages across Cape Breton Island indicates that depositional factors were similar over large areas. This need not imply that the lacustrine environment was continuous over the entire area. Observed shoreline facies (red facies) in contact with the underlying Windsor Group, suggest that the lacustrine limits were locally controlled. Similarity of facies assemblages in vertical succession in such widely separated areas as the Loch Lomond Basin and western Cape Breton Island indicates that processes in each area were controlled by common factors. These must include the number and duration of intermittent marine connections, water depths (shoreline fluctuations), and climate. The availability of terrigenous sediment to the lacustrine basins seems to have been comparable, although much more data would be necessary to establish variations in thickness in a systematic manner. Subsidence rates, and therefore accommodation space, was greater in western Cape Breton Island than in the Loch Lomond Basin, although the general sequence of stratigraphic units is quite comparable in these areas.

\section{SumMARY AND CONCLUSIONS}

The lower Mabou Group was deposited in a basin undergoing a fundamental change from marine to evaporiticmarine and terrestrial to a terrestrial environment. Lacustrine conditions replaced former marine evaporite conditions, coincident with climate change from arid to seasonal wet-dry conditions. The lacustrine environments of the lower Mabou Group eventually gave way to fluviatile environments of the upper Mabou Group. The transformation of the Mabou Group from lacustrine to fluviatile was transitional, as shown by intertonguing red beds in the grey facies that increase in thickness and abundance toward the top. In addition to facies changes, fauna identified by Copeland (1957) attest to a change from brackish-water species intercalated with freshwater species in the lower Mabou Group to dominantly freshwater species in the upper Mabou Group.

Evidence for a lacustrine environment outweighs that for a marine setting. The lack of marine fossils suggests that true marine conditions were never reached during Mabou sedimentation. With an inferred flat-floored basin for the setting of the Mabou Group, the local position of the lake margins may have been highly variable with small-scale waterlevel fluctuations causing exposures of large areas (Platt and Wright, 1991). Low energy levels of the water are implied by the presence of low-amplitude ripple marks and rhythmically laminated shales. Large exposed areas would explain the development of desiccation cracks and rooted zones in Mabou sediments. The presence of these subaerial features coupled with ripple marks, stromatolites, and ooids indicate fluctuating water-levels. Picard and High (1972) stated that characteristics diagnostic of lakes include a lack of marine forms, stressed communities, and a close association with fluvial units, and concluded by stating that no single criterion is sufficient to indicate ancient lacustrine deposits.

The carbonate rocks, although not diagnostic of any environment on their own, contribute to the understanding of the lower Mabou Group, in terms of overall environmental conditions, stressing the presence of a subaqueous environment undergoing intermittent periods of subaerial exposure. 


\section{ACKNowledgements}

I would like to thank P.S. Giles for many helpful discussions and critical reviews of this paper, and encouragement. The manuscript was greatly improved from reviews by M.R. Gibling (Dalhousie University) and R.C. Boehner (Nova Scotia Department of Natural Resources). Financial support for field investigations was provided by the Geological Survey of Canada through the Canada - Nova Scotia Cooperation Agreement on Mineral Development.

Bathurst, R.G.C. 1975. Carbonate Sediments and Their Diagenesis Elsevier, Amsterdam.

Bell, W.A. 1944. Carboniferous rocks and fossil floras of northern Nova Scotia. Canada Geological Survey, Memoir 238 , p. 277.

---- 1958. Possibilities for Occurrence of Petroleum Reserves in Nova Scotia. Nova Scotia Department of Mines Report, p. 177

Bell, J.S. and Howie, R.D. 1990. Paleozoic geology. In Geology of the Continental Margin of Eastern Canada, Chapter 4. Edited by M.J. Keen and G.L. Williams. Geological Survey of Canada, Geology of Canada, 2, pp. 141-165.

Bell, W.A. and Goranson, E.A. 1938. Sydney Sheet (west half). Department of Mines and Resources, Canada, Map 360A.

Belt, E.S. 1964. Revision of Nova Scotia Middle Carboniferous Units. American Journal of Science, 262, pp. 653-673.

-..-- 1965. Stratigraphy and Paleogeography of Mabou Group and Related Middle Carboniferous Facies, Nova Scotia, Canada. Geological Society of America, Bulletin 76, pp. 777-802.

..... 1968. Carboniferous Continental Sedimentation, Atlantic Provinces, Canada. In Late Paleozoic and Mesozoic Continental Sedimentation, Northeastern North America. Edited by G. de V. Klein. Geological Society of America, Special Paper 106, pp. 127-176.

BOEHNER, R.C. 1980. Geology, geochemistry, and geophysics of the Shubenacadie - Stewiake salt deposit, Hans and Colchester Counties, Nova Scotia. Nova Scotia Department of Mines and Energy, Report 80-1, pp. 165-186.

...- 1984. Sydney Basin Project - An update. Nova Scotia Department of Mines and Energy, Report 84-1, pp. 49-60.

-.-- 1985. Carboniferous basin studies, salt, potash, celestite and barite - new exploration potential in the Sydney Basin, Cape Breton Island. Nova Scotia Department of Mines and Energy, Report 85-1, pp. 153-164.

Boehner, R.C. and Giles, P.S. 1993. Geology of the Antigonish Basin, Antigonish County, Nova Scotia. Nova Scotia Department of Natural Resources, Mines and Energy Branches, Memoir 8, p. 108.

Boehner, R.C. and Prime, G. 1993. Geology of the Loch Lomond Basin and Glengarry Half Graben, Richmond and Cape Breton Counties, Cape Breton Island, Nova Scotia. Nova Scotia Department of Natural Resources, Mines and Energy Branches, Memoir 9, p. 68

Burchette, T.P. and Riding, R. 1977. Attached vermiform gastropods in Carboniferous marginal marine stromatolites and biostromes. Lethaia, 10, pp. 17-28.

Copeland, M.J. 1957. The arthropod fauna of the upper Carboniferous rocks of the Maritime Provinces. Geological Survey of Canada, Memoir 286, p. 110.

Davies, P.J., Bubela, B., and Ferguson, J. 1978. The formation of ooids. Sedimentology, 25, pp. 703-730.

Dunham, R.J. 1962. Classification of carbonate rocks according to depositional texture. In Classification of Carbonate Rocks. Edited by W.E. Ham. American Association of Petroleum Geologists, Memoir 1, pp. 108-121.

Eugster, H.P. and Hardie, L.A. 1975. Sedimentation in an ancient playa-lake complex: The Wilkins Peak Member of the Green River Formation, Wyoming. Geological Society of America, Bulletin 86, pp. 319-334.

GIBLING, M.R. and BIRD, D.J. 1994. Late Carboniferous cyclothems and alluvial paleovalleys in the Sydney Basin, Nova Scotia. Geological Society of America, Bulletin 106, pp. 105-177.

GILES, P.S. 1981. Major transgressive-regressive cycles in Middle to Late Visean rocks of Nova Scotia. Nova Scotia Department of Mines and Energy, Paper 81-2, p. 27.

-.--- 1983. Sydney Basin Project. Nova Scotia Department of Mines and Energy Report, 83-1, pp. 57-70.

Giles, P.S., Hein, F.J., and Allen, T.L. In press (a). Bedrock geology of Port Hood-Lake Ainslie (11K04, 11K03, 11F13), Cape Breton Island, Nova Scotia. Geological Survey of Canada, Open File, 1:50 000 map with marginal notes.

-.--- In press (b). Bedrock geology of Margaree (11K06), Cape Breton Island, Nova Scotia. Geological Survey of Canada, Open File, 1:50 000 map with marginal notes.

Hofmann, H.J. 1973. Stromatolites: Characteristics and Utility. Earth-Science Reviews, 9, pp. 339-373.

Logan, B.W., Rezak, R., and Ginsburg, R.N. 1964. Classification and environmental significance of algal stromatolites. Journal of Geology, 72, pp. 68-83.

Longman, M.W. 1980. Carbonate Diagenetic Textures from Nearshore Diagenetic Environments. American Association of Petroleum Geologists, Bulletin 64, pp. 461-488.

LYNCH, G. and Giles, P.S. In press. The Ainslie Detachment - a regional flat-lying extensional fault in the Carboniferous evaporitic Maritimes Basin of Nova Scotia, Canada. Canadian Journal of Earth Sciences.

MoORE, R.G. and Austin, I.A. 1979. Herbert River and Musquodoboit Limestone Members, keys to reconstruction of the Fundy Depositional Trough, Late Windsor time, Atlantic Area of Canada. Compte Rendu, 3, pp. 179-192.

Neves, R. and Belt, E.S. 1970. Some observations of Namurian and Viséan spores from Nova Scotia, Britain and Northern Spain. Sixième Congrès International de Stratigraphie et de Géologie du Carbonifère, Sheffied, 1967, Compte Rendu, 3, pp. 1233-1249.

Norman, G.W.H. 1935. Lake Ainslie map-area, Nova Scotia. Geological Survey of Canada, Memoir 177, p. 103.

PARK, R. 1976. A note on the significance of laminations in stromatolites. Sedimentology, 23, pp. 379-393.

Picard, M.D. and High, L.R. 1972. Criteria for recognizing lacustrine rocks. In Recognition of Ancient Sedimentary Environments. Edited by J.K. Rigby and W.K. Hamblin. Society of Economic Paleontologists and Mineralogists, Special Publication 16, pp. 108-145.

Platt, N.H. and Wright, V.P. 1991. Lacustrine carbonates: facies models, facies distribution and hydrocarbon aspects. In Lacustrine Facies Analysis. Edited by P. Anadón, Ll. Cabrera, and K. Kelts. Special Publication of the International Association of Sedimentologists, 13, pp. 57-74.

Reijers, T.J.A. and ten Have, A.H.M. 1983. Ooid zonation as indication for environmental conditions in a Givetian-Frasnian carbonate shelf-slope transition. In Coated Grains. Edited by T.M. Peryt. Springer-Verlag, Berlin Heidelberg, pp. 188 198.

Retallack, G.J. 1988. Field recognition of paleosols. Geological Society of America, Special Paper 216, pp. 1-20.

ROSTOKER, M.D. 1960. The geology of the Canso Group in the 
Maritime Provinces, Canada. Ph.D. thesis, Boston University, Boston, Microfilm 60-3484.

Schenk, P.E. 1969. Carbonate-sulphate-redbed facies and cyclic sedimentation of the Windsorian Stage (Middle Carboniferous), Maritime Provinces. Canadian Journal of Earth Sciences, 6, pp. 1037-1066.

Schenk, P.E., von Bitter, P.H., and Matsumoto, R. 1994. Deepbasin/deep-water carbonate-evaporite deposition of a saline giant: Loch Macumber (Visean), Atlantic Canada. Carbonates and Evaporites, 9, pp. 187-210.

Sellwood, B.W. 1986. Shallow-marine carbonate environment. In Sedimentary Environments and Facies. Edited by H.G. Reading. Blackwell, Oxford, pp. 283-342.

Simone, L. 1981. Ooids: A Review. Earth-Science Reviews, 16, pp. 319-355.

StACEY, M.C. 1953. Stratigraphy and paleontology of the Windsor Group (Upper Mississippian) in parts of Cape Breton Island, Nova Scotia. Nova Scotia Department of Mines, Memoir 2, p. 143.

Swirydczuk, K., Wilkinson, B.H., and Smith, G.R. 1979. The Pliocene Glenns Ferry Oolite: Lake-margin carbonate deposition in the southwestern Snake River Plain. Journal of Sedimentary Petrology, 49, pp. 995-1004.

TASCH, P. 1980. Paleobiology of the Invertebrates: Data Retrieval From the Fossil Record. John Wiley and Sons, New York, Chichester, Brisbane, Toronto, pp. 441-470.
Thibaudeau, S.A. 1993. Agglutinated brackish water foraminifera and arcellaceans from the Upper Carboniferous, coalbearing strata of the Sydney Basin, Nova Scotia: taxonomic descriptions, assemblages, and environments of deposition. M.Sc. thesis, Dalhousie University, Halifax, Nova Scotia.

TUCKER, M.E. 1978. Triassic lacustrine sediments from South Wales: shore-zone clastics, evaporites and carbonates. In Modern and Ancient Lake Sediments. Edited by A. Matter and M.E. Tucker. Special Publication Number 2 of the International Association of Sedimentologists, pp. 205-224.

Utring, J. 1987. Palynology of the Lower Carboniferous Windsor Group and Windsor-Canso boundary beds of Nova Scotia and their equivalents in Quebec, New Brunswick and Newfoundland. Geological Survey of Canada, Bulletin 374, p. 93.

WeEdon, M.J. 1990. Shell structure and affinity of vermiform 'gastropods'. Lethaia, 23, pp. 297-309.

Wightman, W.G., Scott, D.B., Medioli, F.S., and Gibling, M.R. 1993. Carboniferous marsh foraminifera from coal-bearing strata at the Sydney Basin, Nova Scotia: a new tool for identifying paralic coal-forming environments. Geology, 21, pp. 631634.

Editorial Responsibility: P. Giles and G.L. Williams 